\title{
Histamine activates inflammatory response and depresses casein synthesis in mammary gland of dairy cows during SARA
}

\author{
Guangjun Chang ${ }^{\dagger}$, Lailai Wang ${ }^{\dagger}$, Nana Ma, Wenwen Zhang, Huanmin Zhang, Hongyu Dai and Xiangzhen Shen ${ }^{*}$ (D)
}

\begin{abstract}
Background: Mounting evidences observed that subacute ruminal acidosis (SARA) induced by high concentration $(\mathrm{HC})$ diet increases the translocation of histamine from digestive tract into circulation causing a diverse of diseases in dairy cows. However, it is largely unknown how it does affect the function of mammary gland and milk quality. Hence, this study aims to observe the effects of histamine derived from the digestive tract on the inflammatory response and casein synthesis in the mammary glands during SARA. Twelve cows fitted rumen fistula were randomly divided into either control group administrated low concentration (LC) diet (60\% forage, $n=6)$ or treatment group administrated HC diet (40\% forage, $n=6)$ for 18 weeks.

Results: Our data showed that HC diet resulted in significant declines in rumen pH value, milk yield and milk quality, as well as longer duration of averaged pH value below 5.6 per day (more than $180 \mathrm{~min}$ ) compared to LC diet, these findings confirmed SARA occurence. Our study also observed that SARA increased the content of histamine in rumen fluid, plasma, liver and mammary gland, and enhanced the mRNA expression of histamine specific receptor in the mammary gland. Additionally, we found that the mRNA expression of inflammatory response genes in mammary glands was increased, which was consistent with the protein expression results, showing that the protein kinase C(PKC) / nuclear factor kappa B (NF-KB) or protein kinase A (PKA) / NF-KB signalling pathways of the inflammatory response were activated. The mRNA expression of mTOR, P70S6K and aS1 in mammary glands were significantly decreased with the protein expression of mTOR, P70S6K and aS1-casein, and the phosphorylation levels of the mTOR and P70S6K proteins were also decreased.

Conclusions: Our study showed that the milk protein of lactating cows is depressed after long-term feeding of $\mathrm{HC}$ at the individual level, which was paralleled at the gene and protein levels. The inflammatory response in mammary gland caused by histamine derived from the digestive tract is related to the decline of casein synthesis. Our findings point to a new link between the inflammatory response and casein synthesis, but the understanding of the molecular mechanisms involved in this process will require further research.
\end{abstract}

Keywords: Mammary gland, Histamine receptor, NF-KB and mTOR signalling pathway, Casein, Inflammatory response

\section{Background}

Subacute ruminal acidosis (SARA) that is a common and frequent metabolic disorder disease can bring tremendous economic losses to dairy industry. The most important reason for SARA occurrence is that to maintain a high yield of milk, the nutrient density of dairy cow diets has increased [1]. The adjustment of the

\footnotetext{
* Correspondence: xzshen@njau.edu.cn

Guangjun Chang and Lailai Wang contributed equally to this work.

College of Veterinary Medicine, Nanjing Agricultural University, Nanjing, Jiangsu, China
}

nutrient density is mainly through the feeding of $\mathrm{HC}$ diets. This feeding mode can increase the production of organic acids and cause a depression of the $\mathrm{pH}$ in the digestive tract over time $[2,3]$. When the rumen $\mathrm{pH}$ value of cows falls below 5.6 for more than $3 \mathrm{~h}$ per day, SARA occurs. This decrease in $\mathrm{pH}$ may result in alterations in the type of fermentation and the composition of the microbiota in the rumen [4]. When the rumen has a low $\mathrm{pH}$, the different types of bacteria make histidine for decarboxylization to produce histamine [5]. Histamine that is absorbed from the gastrointestinal tract can be

(c) The Author(s). 2018 Open Access This article is distributed under the terms of the Creative Commons Attribution 4.0 International License (http://creativecommons.org/licenses/by/4.0/), which permits unrestricted use, distribution, and 
rapidly detoxified by amine oxidases in healthy subjects, and it also can be produced by epithelial cell to regulate many physiological processes, such as cell growth and differentiation [6]. The acid-induced impairment of epithelial barrier function facilitates the translocation of histamine from the digestive tract into the bloodstream [7]. The increase of histamine in blood can cause systemic histaminosis such as laminitis, which is a popular dieses in dairy farm [1], and it is also closely associated with inflammation and lactation of mammary gland $[6,8]$, those observations suggested that histamine originated from gastrointestinal tract entering mammary gland may elicits local inflammation, and then affects lactation of mammary gland and milk quality.

Histamine (2-[4-imodazole]-ethylamine, HIS) is synthesized by the decarboxylation of histidine by Lhistidine decarboxylase (HDC), which is dependent on the cofactor pyridoxal- $5^{\prime}$-phosphate [9]. After histamine interacts with its receptors $\left(\mathrm{H}_{s} \mathrm{R}\right)$, of which there are four subtypes $\left(\mathrm{H}_{1} \mathrm{R}, \mathrm{H}_{2} \mathrm{R}, \mathrm{H}_{3} \mathrm{R}\right.$ and $\left.\mathrm{H}_{4} \mathrm{R}\right)$ that all belong to the family of $\mathrm{G}$ protein-coupled receptors, it will exert many (patho-) physiological effects [10]. $\mathrm{H}_{1} \mathrm{R}$-coupled $\mathrm{G \alpha}_{\mathrm{q} / 11}$ can generate inositol-1, 4, 5-triphosphate and diacylglycerol and increase the intracellular calcium content through stimulating the inositol phospholipid signalling pathways, which has been demonstrated to activate NF- $\mathrm{kB}[11,12] . \mathrm{H}_{2} \mathrm{R}$-coupled $\mathrm{G \alpha}_{\mathrm{s}}$ can, through separate guanosine triphosphate-dependent mechanisms, activate adenylate cyclase and the phosphoinositide second messenger-cAMP to produce gastric acid and mucus $[13,14] . H_{3} R$ is mainly present in nervous system signal transduction, and it can lead to the inhibition of cAMP, the accumulation of $\mathrm{Ca}^{2+}$ and the activation of the mitogen-activated protein kinase pathway to release neurotransmitters when it is coupled with $\mathrm{G \alpha}_{\mathrm{i} / \mathrm{o}}$ [15]. $\mathrm{H}_{4} \mathrm{R}$ has been reported to couple with $G \alpha_{\mathrm{i} / \mathrm{o}}$ and play an important role in binding sites for interferon regulatory factor and NF- $\mathrm{kB}$ in the modulation of the immune system $[16,17]$.

Milk is a mixture of several ingredients, including water, fat, protein, lactose and inorganic salt. Meanwhile, casein is a complex particle containing calcium and phosphateand accounts for $80 \% \sim 82 \%$ of the total amount of protein in milk. Casein has the following four groups: $\alpha \mathrm{S} 1$-casein, $\alpha \mathrm{S} 2$-casein, $\beta$-casein and $\mathrm{k}$-casein [18]. In dairy cows, the most abundantly expressed milk protein is $\alpha \mathrm{S} 1$ - casein. Janus kinase (JAK), the signal transducer and activator of transcription (STAT) signalling pathway and the mTOR signalling pathway are the primary pathways in milk protein expression. However, it has been reported that the role of the JAK-STAT signalling pathway is weak in regulating bovine milk protein expression [19], because the synthesis of $\alpha \mathrm{S} 1$-casein is translational but not transcriptionally regulated.
Previous studies have demonstrated that histamine can induce inflammation; however, it is unknown whether histamine derived from the digestive tract during SARA is capable of influencing inflammatory responses and casein synthesis in the mammary gland of dairy cows. Therefore, we hypothesized that the present study could investigate the effects of histamine derived from the digestive tract during SARA on the inflammatory response and casein synthesis in the mammary gland of lactating dairy cows fed high concentration (HC) diets.

\section{Methods}

All experimental procedures were approved by the Animal Experiment Committee of Nanjing Agricultural University, in accordance with the Regulations for the Administration of Affairs Concerning Experimental Animals (The State Science and Technology Commission of China, 1988). All the experimental protocols were performed in accordance with the approved guidelines and regulations.

\section{Animals, diets, and experimental design}

Twelve multiparous lactating Holstein cows were housed in individual tie- stalls in dairy farm of Nanjing Agricultural University and fitted with a rumen fistula (3-5 weeks post-partum, aged 3-5 years and averaged body weight $460 \pm 25 \mathrm{~kg}$ ) displayed an averaged milk yield $29 \pm 3.17 \mathrm{~kg} /$ day at the beginning and $27 \pm 2.76 \mathrm{~kg} /$ day at the end of the present experiment. All cows were fed low concentration (LC) diet for 1 month to reach a similar metabolic state, and then randomly divided into two groups. One group $(n=6)$ was administrated $\mathrm{HC}$ diet comprising $60 \%$ concentrate and $40 \%$ forage as treatment group, while another group $(n=6)$ was fed LC diet comprising $40 \%$ concentrate and $60 \%$ forage as control group. The experiment was lasted for 18 weeks. The details of the dietary ingredients and nutritional composition are presented in Table 1 . Cows had fresh water for free drinking and were milked and fed at 04:00, 12:00, and 20:00 during the experiment.

\section{Rumen $\mathrm{pH}$ and milk measurements}

The $\mathrm{pH}$ value was measured by a $\mathrm{pH}$-meterat $1 \mathrm{~h}$ intervals for $24 \mathrm{~h}$ on the last 3 days of 18th week. Milk yield was measured at each of the 3 milkings on experimental days of the $1^{\text {st }}$ week and 18 th week. Milk sample $(50 \mathrm{~mL})$ was also taken from the mixture of 3 milkings of each cow on these days, and then it was added potassium dichromate and stored at $4{ }^{\circ} \mathrm{Cfor}$ the measurement of milk protein and fat with the Milko $\operatorname{Scan}^{\mathrm{Tw}}$ FT1device (Foss, Denmark). At $4 \mathrm{~h}$ after feeding on the last day of 18th week, Rumen content and fluid were mixed, and then the mixture was taken via rumen fistula, and 
Table 1 Ingredients of low concentrate and high concentrate diet

\begin{tabular}{llll}
\hline Item & Ingredient & LC & HC \\
\hline Forage & Corn silage & 30.00 & 20.00 \\
Concentrate & Alfalfa hay & 30.00 & 20.00 \\
& Corn & 22.78 & 33.60 \\
& Bran & 5.15 & 15.00 \\
& Soybean meal & 9.80 & 9.00 \\
& Calcium phosphate dibasic & 0.92 & 0.53 \\
& Limestone & 0.00 & 0.52 \\
& Salt & 0.35 & 0.35 \\
& Premix ${ }^{\mathrm{a}}$ & 1.00 & 1.00 \\
& Total & 100.00 & 100.00 \\
NE(MJ/Kg) & 6.32 & 6.74 \\
CP (\%) & 16.00 & 16.20 \\
& EE (\%) & 3.96 & 4.15 \\
& NDF (\%) & 37.71 & 31.92 \\
ADF (\%) & 22.75 & 17.55 \\
NFC (\%) & 33.43 & 40.31 \\
Starch (\%) & 25.33 & 32.28 \\
Ca (\%) & 0.90 & 0.80 \\
P (\%) & 0.45 & 0.45 \\
\hline
\end{tabular}

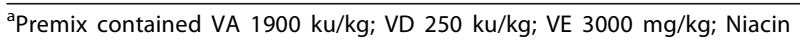
4000 mg/kg; Cu 1200 mg/kg; Fe 525 mg/kg; Zn 13,000 mg/kg; Mn $5500 \mathrm{mg} / \mathrm{kg}$; I $170 \mathrm{mg} / \mathrm{kg}$; Co $50 \mathrm{mg} / \mathrm{kg}$; Se $27 \mathrm{mg} / \mathrm{kg}$

$L C$ low concentration diet, $H C$ high concentration diet

squeezed to obtain rumen fluid $(50 \mathrm{~mL})$, which subsequently was filtered by four layer gauze. The filtrate was centrifuged at $10000 \times \mathrm{g}$ for $30 \mathrm{~min}$, and then the supernatant was stored at $-20{ }^{\circ} \mathrm{C}$ for further histamine determination.

\section{Tissue and blood samples collection}

On the last 3 days of the 18thweek, Blood were collected $4 \mathrm{~h}$ after feeding via the lacteal artery into 5-ml heparinised vacuum tubes, and plasma was isolated by centrifugation at $1900 \times \mathrm{g}$ for $15 \mathrm{~min}$ and stored at $-20{ }^{\circ} \mathrm{C}$ for histamine determination. Approximate $10 \mathrm{~g}$ of Mammary gland tissue of each cow was harvested by biopsy from a deeper location of the right hind quarter. One small portion (about $0.5 \mathrm{~g}$ ) supplemented with phosphate buffer saline (PBS, $0.5 \mathrm{~mL}$ ) was homogenized using a Dounce homogenizer and centrifuged at $3000 \times \mathrm{g}$ for $10 \mathrm{~min}$, and then the supernatant was stored at $-20{ }^{\circ} \mathrm{C}$ for histamine determination. Another portion of mammary gland tissue was stored at $-80{ }^{\circ} \mathrm{C}$. After sampling the mammary gland, the cows were slaughtered, and the liver tissue was collected aseptically within 5 to $10 \mathrm{~min}$ after killing, then liver tissue samples were cut into several smaller tissue pieces (about $0.5 \mathrm{~g}$ ), which was prepared following the processing protocol of mammary gland for histamine determination and stored at. $-20{ }^{\circ} \mathrm{C}$.

\section{Enzyme-linked immunosorbent assay}

Histamine concentrations in rumen fluid, plasma, liver and mammary gland tissue were determined with a double-antibody sandwich enzyme-linked immunosorbent assay (cat.H171, JIANCHENG, China). According to the instruction of manufacturer, diluted histamine standard $(1600 \mathrm{ng} / \mathrm{mL}$ to $100 \mathrm{ng} / \mathrm{mL})$ and prepared samples was added to the monoclonal antibody enzyme well, which was pre-coated with bovine HIS monoclonal antibody, followed by incubation. Then, histamine antibody labelled with biotin was added and combined with Streptavidin-HRP to form an immune complex. The plate was incubated and washed 5 times to remove the uncombined enzyme. After the addition of Chromogen Solution A and B, the plate was read by the Microplate Reader (Bio-TekELX80, USA) to obtain the optical density value (OD value). The standard curve was made according to the OD value and corresponding concentration. Histamine concentration in the samples was calculated by the standard curve.

\section{RNA extraction, CDNA synthesis and real-time polymerase} chain reaction (PCR)

Total RNA was extracted using TRIzol following the instructions of the kit (cat.9108, Takara, Dalian, China). The concentration and the quality of the RNA were detected using a NanoDrop ND-1000 Spectrophotometer (ThermoFisher Scientific Inc., Waltham, USA). $400 \mathrm{ng}$ of the total RNA was used to synthesize cDNA through the PrimeScript RT Master Mix Perfect Real Time kit (cat.RR036A, Takara, Dalian, China). The real-time PCR was conducted using the SYBR Premix Ex TaqTM kit (cat. DRR420A, Takara, Dalian, China) on an ABI 7300 Real-Time PCR System (Applied Biosystems, Foster City, CA, USA). The PCR protocol was denaturation at $95{ }^{\circ} \mathrm{C}$ for $15 \mathrm{~s}$, then 40 cycles at $95{ }^{\circ} \mathrm{C}$ for $5 \mathrm{~s}$, and $60{ }^{\circ} \mathrm{C}$ for 31 s. Glyceraldehyde phosphate dehydrogenase (GAPDH) was used as the internal reference gene. The primers were designed using Primer Premier Software 5.0 (Premier Biosoft International, USA) and synthesized by Generay Company (Shanghai, China), and the primer details are shown in Table 2. The $2^{-\Delta \Delta} \mathrm{Ct}$ method was used to analyse the results.

\section{Western blotting}

Total protein was extracted from frozen mammary gland tissues. One hundred $\mathrm{mg}$ of frozen minced mammary tissues and $1 \mathrm{~mL}$ ice-cold RIPA lysis buffer (cat. SN338, Sunshine Biotechnology Co., Ltd., 
Table 2 The primer list for reverse transcription and amplification of RT-qPCR

\begin{tabular}{|c|c|c|c|c|}
\hline Gene & NCBI Accession & PCR product & Forward Primer $\left(5^{\prime}-3^{\prime}\right)$ & Reverse Primer $\left(5^{\prime}-3^{\prime}\right)$ \\
\hline $\mathrm{H}_{1} \mathrm{R}$ & NM_174083.4 & $245 b p$ & AGCCAGAACCAGCTTGAGAT & TTCATGTGCAAGCCAGACAC \\
\hline $\mathrm{H}_{2} \mathrm{R}$ & XM_015464941.1 & $198 b p$ & TTGGCAAGGTCTTCTGCAAC & GGAAGGACAGGGTGATGGAA \\
\hline $\mathrm{H}_{3} \mathrm{R}$ & XM_015466045.1 & $172 b p$ & CAGAAGATGGTGCTGGTGTG & AAGGGGTGAAGAACTCGAGG \\
\hline $\mathrm{H}_{4} \mathrm{R}$ & XM_001251983.5 & $221 b p$ & ATCCTTGCCCTCACGTTAGT & CGAAGGGATGCTGCTGATTC \\
\hline$I L-1 \beta$ & NM_174093.1 & $167 b p$ & GGCCAAAGTCCCTGACCTCT & CTGCCACCATCACCACATTC \\
\hline TNF-a & NM_173966.3 & $261 b p$ & CACATACCCTGCCACAAGGC & CTGGGGACTGCTCTTCCCTCT \\
\hline NF-KB & NM_001045868.1 & $129 b p$ & ATACGTCGGCCGTGTCTAT & GGAACTGTGATCCGTGTAG \\
\hline mTOR & XM_001788228.1 & $199 b p$ & ATGCTGTCCCTGGTCCTTATG & GGGTCAGAGAGTGGCCTTCAA \\
\hline P70S6K & NM_205816.1 & $162 b p$ & GGACATGGCAGGGGTGTTT & GGTATITGCTCCTGTTACTITCG \\
\hline 4EBP1 & BC120290.1 & $177 b p$ & GGCAGGCAGTGAAGAGTC & CCTGGGCTGCGGGAT \\
\hline aS1-casein & NM_181029.2 & $170 b p$ & ATTITCAGACAATTCTACCAGCT & AATTCACTTGACTCCTCACCAC \\
\hline GAPDH & NM_001034034.2 & $135 b p$ & TGTTGTGGATCTGACCTGCC & AAGTCGCAGGAGACAACCTG \\
\hline
\end{tabular}

Shanghai, China) were mixed and homogenized using a Dounce homogenizer. The supernatant was collected after centrifugation at $12,000 \mathrm{rpm}$ for $15 \mathrm{~min}$ at $4{ }^{\circ} \mathrm{C}$. The protein concentration was measured using a BCA Protein Assay kit (cat.23225, ThermoFisher, USA) and then diluted to the same concentration. Fifty $\mu$ g of protein from each sample was loaded onto $8 \sim 12 \%$ sodium dodecyl sulphate polyacrylamide gel electrophoresis (SDS-PAGE) gels. After separation, the proteins were transferred to a nitrocellulose (NC) membrane (Pall Gelman Laboratory, USA). The membrane was blocked with $6 \sim 7 \%$ nonfat dry milk (dissolved in Tris-Buffered Saline with Tween, TBST) or 6 7\% BSA (for phosphorylated protein) for $2 \mathrm{~h}$ at room temperature. Afterwards, the NC membrane was washed and incubated with TBST-diluted primary antibody at $4{ }^{\circ} \mathrm{C}$ overnight. The primary antibodies were used in previous study [20], and diluted at the following ratios: NF- $\mathrm{B}$ p65 (1:500; cat.AN365, Beyotime, China), phosphorylated NF-кB p65 (1:500; cat.AN371, Beyotime, China), IL6 (1:200; cat.sc-1265, Santa Cruz, USA), GAPDH (1:5000; cat.AP0066, Bioworld, USA), $\alpha$ S1-casein (1:400; cat.sc376,961, Santa Cruz, USA), mTOR (1:500; cat.sc-8319, Santa Cruz, USA), phosphorylated mTOR (1:500; cat.sc101,738, Santa Cruz, USA), P70S6K (1:500; cat.sc-9027, Santa Cruz, USA) and phosphorylated P70S6K (1:500; cat. sc-7984R, Santa Cruz, USA). The membranes were then washed and incubated with the corresponding secondary antibodies for $2 \mathrm{~h}$ at room temperature. The secondary antibodies were as follows: goat anti-rabbit (1:10000; cat. sc-2004, Santa Cruz, USA) for NF-кBp65, NF-кBpp65, IL-1 $\beta$, P70S6K, mTOR, pP70S6K, and pmTOR; goat antimouse (1:10000; cat.sc-2005, Santa Cruz, USA) for $\alpha \mathrm{S} 1$ casein; rabbit anti-goat (1:10000; cat.sc-2768, Santa Cruz, USA) for GAPDH. Finally, the membranes were treated with an enhanced chemiluminescence (ECL) detecting kit
(E411-04, Vazyme Biotech Co.,Ltd., Nanjing, China). The signals were recorded through an imaging system (LAS4000, USA), and the results were analysed using Quantity One software (Bio-Rad, USA).

\section{Statistical analysis}

Data from milk and rumen $\mathrm{pH}$ was analyzed using repeated model of MIXED procedure of SAS (SAS version 9.4, SAS Institute Inc.). The effects of diet and days were considered as fixed factors, and goat was treated as random factor. Days with diet and goat was considered as repeated measure, and compound symmetry (CS) was used as the type of covariance. Data about histamine concentration, mRNA and protein expression was analyzed using ANOVA procedure of SAS. The significant difference was considered to occur when $P<0.05$.

\section{Results}

Ruminal pH, milk yield and milk composition

Compared with LC diet, HC diet was significantly decreased the mean rumen $\mathrm{pH}$ value and increased the duration of rumen $\mathrm{pH}<5.6 /$ day, which was longer than 180 min per day after $18^{\text {th }}$ week feeding.(Table 3). Additionally, the feeding of $\mathrm{HC}$ diet caused an increased tendency in milk yield and significant increase in milk fat in the 1st week, whereas resulted in significant decline in milk yield, milk protein and milk fat in the $18^{\text {th }}$ week compared to the feeding of LC diet.

\section{Histamine content in rumen fluid, blood, liver tissues and mammary gland tissues in dairy cows}

The mean histamine values in rumen fluid, blood, liver tissue and mammary gland tissue were measured and the results presented in Fig. 1 show that the values in the four tissues were significantly different between the $\mathrm{LC}$ and $\mathrm{HC}$ groups. The histamine content in the rumen 
Table 3 Rumen pH, milk yield and composition of dairy cows fed LC or HC diets

\begin{tabular}{|c|c|c|c|c|c|c|}
\hline \multirow[t]{2}{*}{ Item } & \multirow[t]{2}{*}{ LC } & \multirow[t]{2}{*}{$\mathrm{HC}$} & \multirow[t]{2}{*}{ SEM } & \multicolumn{3}{|c|}{$p$-Value } \\
\hline & & & & Diet & Day & Diet $\times$ Day \\
\hline Mean $\mathrm{pH}$ value & 6.02 & 5.90 & 0.03 & $<0.01$ & 0.23 & 0.18 \\
\hline Minimum $\mathrm{pH}$ value & 5.65 & 5.50 & 0.05 & 0.02 & 0.08 & 0.38 \\
\hline Time $<\mathrm{pH} 5.6, \mathrm{~min} / \mathrm{d}$ & 99.00 & 223.00 & 30.25 & 0.01 & 0.06 & 0.57 \\
\hline Milk yield (kg/d) week1 & 28.7 & 30.9 & 0.47 & 0.08 & 0.23 & 0.76 \\
\hline Milk yield (kg/d) week18 & 28.05 & 26.92 & 0.30 & $<0.01$ & 0.05 & 0.41 \\
\hline Milk protein (\%) week1 & 3.34 & 3.41 & 0.03 & 0.11 & 0.53 & 0.79 \\
\hline Milk protein (\%) week18 & 3.02 & 2.88 & 0.04 & 0.01 & 0.51 & 0.31 \\
\hline Milk fat (\%) week1 & 3.48 & 3.34 & 0.02 & 0.21 & 0.61 & 0.58 \\
\hline Milk fat (\%) week18 & 3.54 & 2.94 & 0.04 & 0.02 & 0.12 & 0.81 \\
\hline
\end{tabular}

fluid and blood of the HC group was significantly increased $(P<0.01$; Fig. 1a) compared to the LC group. The histamine content in the liver tissues was higher compared with the liver tissues, and the differences in the liver tissues and mammary tissues between the LC and HC group were both significant $(P<0.01$; Fig. $1 b)$.

\section{mRNA expression of histamine receptors in mammary gland tissues}

The results showed that the different types of histamine receptors in the mammary gland tissues had heterogeneous expression, of which $\mathrm{H}_{4} \mathrm{R}$ had the highest expression, while the expression of $\mathrm{H}_{3} \mathrm{R}$ was the lowest (Fig. 2). $\mathrm{H}_{1} \mathrm{R}, \mathrm{H}_{2} \mathrm{R}$ and $\mathrm{H}_{4} \mathrm{R}$ had significantly different expressions in the LC group and $\mathrm{HC}$ group $(P<0.01)$. There was not a significant difference in $\mathrm{H}_{3} \mathrm{R}$ expression between the $\mathrm{LC}$ and $\mathrm{HC}$ groups.

\section{mRNA expression of inflammatory response genes in} mammary gland tissues

The results showed that NF- $\mathrm{kB}$ mRNA expression in mammary tissues in the $\mathrm{HC}$ group was significantly high $(P<0.01)$ compared to the LC group (Fig. 3a). mRNA expression of tumour necrosis factor (TNF)- $\alpha$ and interleukin(IL)-1 $\beta$ were significantly up-regulated in the $\mathrm{HC}$ group compared with the LC group $(P<0.05)$.

mRNA expression of casein synthesis genes in mammary gland tissues

As shown in Fig. 3b, the mRNA expression of casein synthesis genes was changed by $\mathrm{HC}$ feeding. The mRNA expression of mTOR genes was significantly decreased in the HC group in mammary gland tissues compared with the LC group $(P<0.01)$. The mRNA expression of the $\mathrm{S} 6 \mathrm{~K}$ genes was significantly decreased in the HC group, but the mRNA expression of the 4EBP1 genes was markedly increased $(P<0.01)$ in the $\mathrm{HC}$ group. Importantly, the $\alpha \mathrm{S} 1$-casein genes in the $\mathrm{HC}$ group had significantly decreased mRNA expression compared with the LC group in mammary gland tissues.

\section{Protein expression of inflammatory factors in mammary gland tissues}

Western blotting results (Fig. 4a) showed that the NF$\kappa B p 65$ and NF- $\kappa B$ p 65 protein in mammary glands were

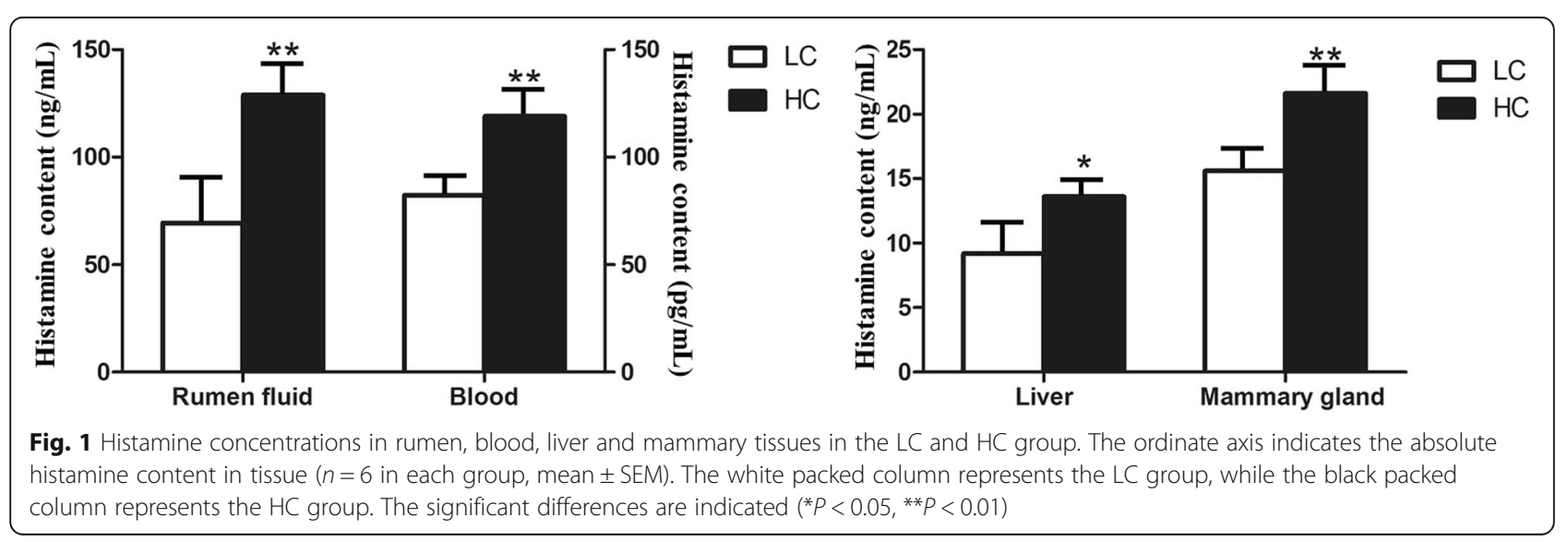




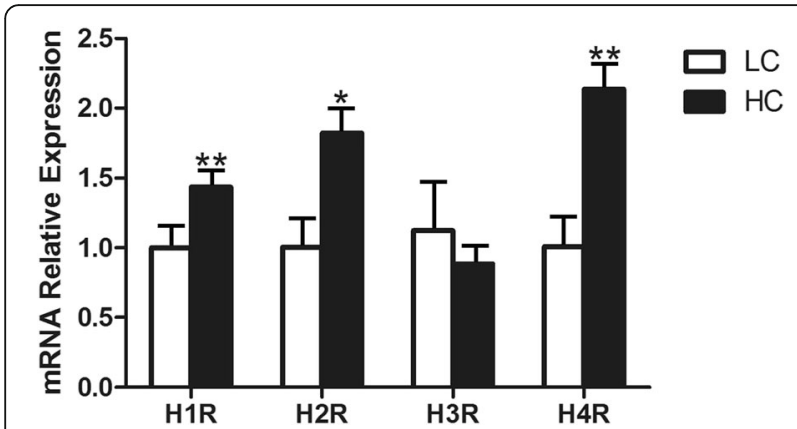

Fig. 2 mRNA expressions of the histamine receptor genes $H_{1} R, H_{2} R$, $\mathrm{H}_{3} \mathrm{R}$ and $\mathrm{H}_{4} \mathrm{R}$ in the mammary tissues of dairy cows in the $\mathrm{LC}$ and $\mathrm{HC}$ groups. The ordinate axis indicates the relative expression of histamine receptors in mammary gland tissues ( $n=6$ in each group, mean \pm SEM). The white packed column represents the LC group, while the black packed column represents the HC group. The significant differences are indicated $\left({ }^{*} P<0.05,{ }^{*} P<0.01\right)$

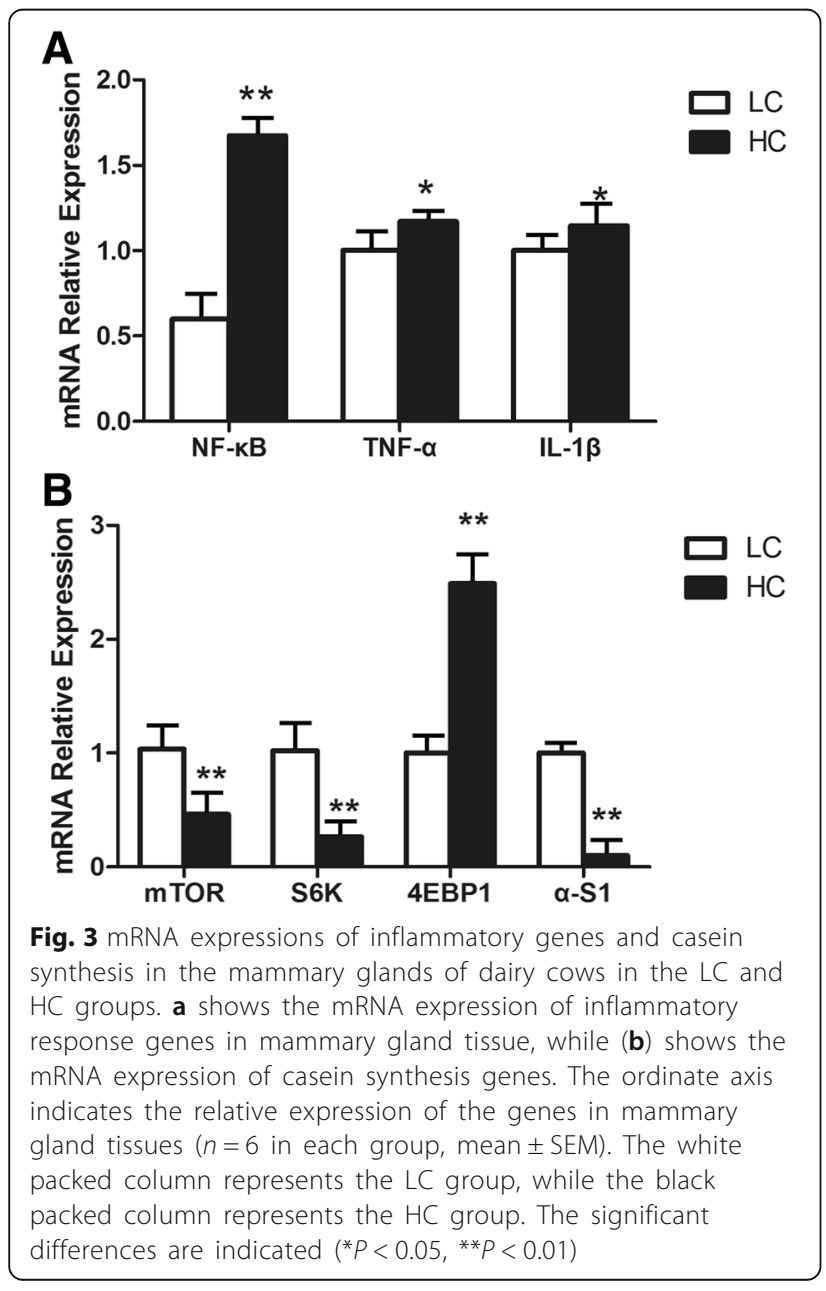

both significantly increased $(P<0.01)$ in the HC group. The significant increase of IL-1 $\beta \quad(P<0.01)$ further demonstrated the inflammation of the mammary gland tissues in the $\mathrm{HC}$ group.

\section{Protein expression of casein synthesis in mammary gland tissues}

Western blotting results (Fig. 4b) showed that the expression of the $\alpha \mathrm{S} 1$-casein, P70S6K, and mTOR proteins in the mammary glands were all decreased in the HC group compared with the LC group $(P<0.01)$. Meanwhile, the phosphorylated proteins $p$ P70S6K and $p$ mTOR were both down-regulated in the $\mathrm{HC}$ group compared with the LC group $(P<0.01)$. The changes of protein levels were consistent with the change in gene expressions. The original western blotting bands for each target protein were shown in Additional file 1.

\section{Discussion}

SARA effects are caused by a combination of ruminal $\mathrm{pH}$ and diet type [21]. The $\mathrm{pH}$ results of the present study demonstrated that the dairy cows had experimentally SARA at the end of experiment through the feeding of an HC diet for 18 weeks, as the defined by the definition of previous study [22]. When SARA occurs, the histamine produced by rumen bacteria can easily pass through the damaged rumen epithelium into the bloodstream and cause inflammation [23, 24].

In fact, the concentrations of histamine in the rumen and plasma both increase during SARA. However, the absorption of histamine in the rumen is the direct cause of the increase in the concentration of histamine in the blood. Under normal conditions, dairy cows contain trace amounts of histamine [23], and when histamine is synthesized, it usually combines with polysaccharide sulphate, heparin and chondroitin sulphate to form inactive complexes stored in mast cell granules. The trace amount of histamine generally undergoes methylation or oxidation in the liver, where it is rapidly converted to a non-active substance in the urine. The results of the present study found that the histamine content is higher in the tissue of the mammary gland than in the tissue of the liver, which may be related to liver clearance. Meanwhile, the results illustrated that the liver has a higher tolerance to histamine than the mammary gland, as the mammary gland is more susceptible to the level of histamine [25].

Histamine can cause inflammation through the $\mathrm{NF}-\mathrm{\kappa B}$ signalling pathway, and this function is realized through combination with its receptors [26].

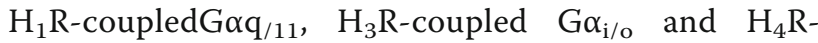
coupled $G \alpha_{i / o}$ can activate PKC and $\mathrm{H}_{2} \mathrm{R}$-coupled $\mathrm{G \alpha}_{\mathrm{s}}$ can activate PKA, both of which can further activate NF- $\kappa B$ through the classical pathway or the 


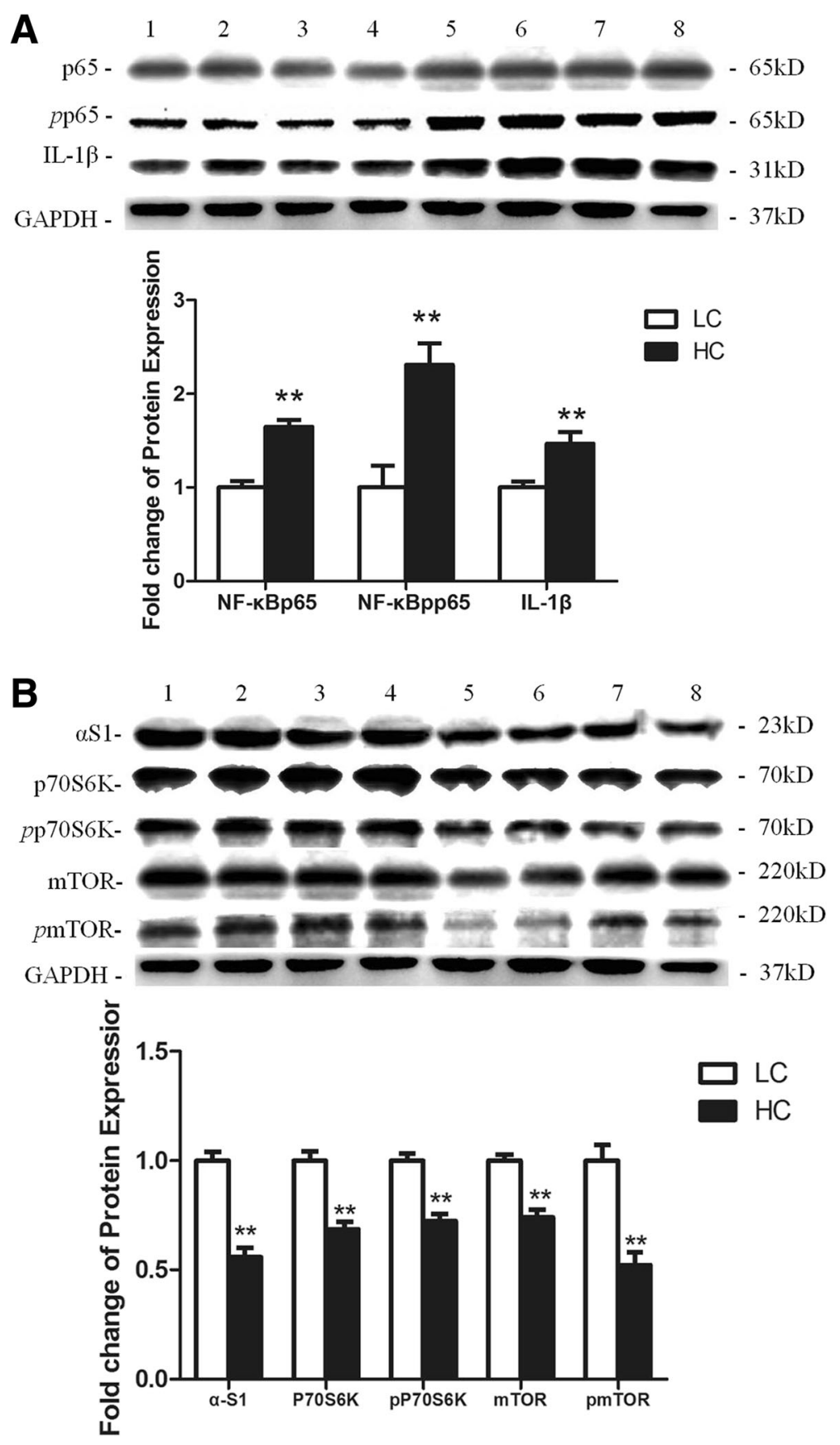

Fig. 4 Protein expressions of several inflammatory factors and casein synthesis in the mammary glands of dairy cows in the LC and HC groups. a shows the protein expression of several inflammatory factors in mammary gland tissue, while (b) shows expression of casein synthesis proteins in the mammary glands of dairy cows in the LC and HC groups. The samples used for western blot derived from the same experiment and the blots for target proteins were conducted in parallel. GAPDH was used as an internal reference protein, and the band density was used to quantify protein expression. The cropped bands 1-4 bands represent the LC group, while 5-8 bands represent the HC group. The significant differences are indicated $\left({ }^{* *} P<0.01\right)$

alternative pathway [27]. Most inflammatory genes contain NF-kB binding sites within their promoters, and therefore once NF- $\mathrm{kB}$ has been activated, it will lead to the secretion of proinflammatory cytokines such as TNF- $\alpha$ and IL-1 $\beta[28,29]$. Our research found that three histamine receptors, $\mathrm{H}_{1} \mathrm{R}, \mathrm{H}_{2} \mathrm{R}$ and $\mathrm{H}_{4} \mathrm{R}$, were significantly increased during SARA, which may be closely related to their function. Histamine activation of $\mathrm{H}_{1} \mathrm{R}$ can change vascular permeability by acting on vascular endothelial cells and 
causing contraction of vascular smooth muscle cells; these features may exacerbate the inflammatory response [30]. Meanwhile, the expression of $\mathrm{H}_{1} \mathrm{R}$ genes can be upregulated by histamine [31]. Compared with $\mathrm{H}_{1} \mathrm{R}$, the absence of histamine can down-regulate the expression of $\mathrm{H}_{2} \mathrm{R}$ genes in a tissue-specific manner [32]. However, unlike $\mathrm{H}_{1} \mathrm{R}$, histamine activation of $\mathrm{H}_{2} \mathrm{R}$ has effects on the relaxation of smooth muscle cells in the blood vessels and inhibition of cytokine production [33]. Recent work has highlighted the major role of $\mathrm{H}_{4} \mathrm{R}$ in eosinophils, mast cells, neutrophils, T-cells and dendritic cells as well as the production of cytokines influenced by these cells, which confirms the importance of this receptor in inflammatory responses [34-37]. We also found that $\mathrm{H}_{3} \mathrm{R}$ expression was not different between the $\mathrm{LC}$ and $\mathrm{HC}$ groups. According to previous studies, $\mathrm{H}_{3} \mathrm{R}$ is an autoreceptor regulating histamine release, and a knockout of $\mathrm{H}_{3} \mathrm{R}$ in mice resulted in an increased severity of neuro-inflammatory diseases with enhanced cytokine release $[38,39]$. The mRNA expression of NF- $\mathrm{kB}$, TNF- $\alpha$ and IL- $1 \beta$ genes was significantly increased in the $\mathrm{HC}$ group, which was consistent with the results of the protein expression levels of NF-кBp65, NF-кBpp65 and IL- $1 \beta$ in the HC group. This showed that the PKC- NF- $k B$ or PKA- NF- $\kappa B$ signalling pathway in the HC group was activated.

It has been reported that the phosphatidyl inositol 3 kinase(PI3K)-serine and threonine protein kinase(Akt)-mTOR signalling pathway plays a major role in casein synthesis. PI3K is activated to convert phosphoinositide 4, 5-bisphosphate (PIP2) into phosphoinositide 3, 4, 5-triphosphate (PIP3) [40]. Then, the growth factor activated kinase Akt is phosphorylated by the products of PI3K in the activation loop (Thr308) and recruited to the plasma membrane [41]. Accordingly, activated Akt can phosphorylate the negative regulator tuberous sclerosis protein-2 (TSC2) and dissociate the TSC complex into TSC1 and TSC2 through the lysosome [42]. Ras homologue enriched in brain (Rheb) is a small guanosine triphosphatase (GTPase) that can activate mTORC1 in its GTP-loaded state, while the GTPaseactivating protein (GAP) activity of TSC2 hydrolyses Rheb-GTP into Rheb-GDP to inactivate mTORC1 [43]. The activated mTORC1 can phosphorylate protein translational regulators P70S6K and eukaryotic cells and translation initiation $4 \mathrm{e}$ binding protein 1(4EBP1) [44]. Phosphorylated P70S6K can stimulate cell growth, while the function of 4EBP1 to stimulate protein translation is inhibited when it is phosphorylated. We found that the mRNA expression of mTOR, P70S6K and $\alpha$-S1 was significantly decreased in the $\mathrm{HC}$ group, in agreement with the protein expression of mTOR, P70S6K and $\alpha-S 1$. Meanwhile, the phosphorylation level of mTOR and P70S6K protein in the $\mathrm{HC}$ group was also decreased. Collectively, the present study indicated that histamine derived from rumen caused the inflammatory response and reduction of casein synthesis in the mammary gland via activating the NF- $\mathrm{kB}$ and mTOR signalling pathway during SARA. It is well known SARA can cause diverse and complex consequences [1], and the present result is only one of consequences and may provide a new way to control inflammatory response of mammary gland elicited by SARA.

\section{Conclusion}

Our research showed that the milk protein of lactating cows is depressed after long-term feeding of $\mathrm{HC}$ at the individual level, which was paralleled at the gene and protein levels. The inflammatory response caused by histamine derived from the rumen is related to reduce casein synthesis. Our findings suggest new relationships between the inflammatory response and casein synthesis, but the understanding of the molecular mechanisms involved in this process will require further research.

\section{Additional file}

Additional file 1: Original western blotting band pictures. (DOCX 11282 kb)

\section{Abbreviations}

HC: High concentration; IL-1ß: Interleukin-1ß; JAK: Janus kinase; LC: Low concentration; NF-kB: Nuclear factor kappa B; PKA: Protein kinase A; PKC: Protein kinase C; SARA: Subacute ruminal acidosis; STAT: The signal transducer and activator of transcription; TNF-a: Tumour necrosis factor-a

\section{Funding}

This study was supported by grants from the National Natural Science Foundation of China (31672618 and 31702301), and the Priority Academic Program Development of Jiangsu Higher Education Institutions (PAPD).

Availability of data and materials

The datasets used during the current study are available from the corresponding author on reasonable request.

\section{Authors' contributions}

GC and LW carried out this experiment. GC drafted the manuscript, NM and $W Z$ prepared the blood and the tissue samples. LW and $\mathrm{HZ}$ contributed to the statistical analyses and drafted the images, XS conceived the idea, and designed the experiment. XS finalized the manuscript. All authors contributed to interpret and discuss the manuscript. All authors read and approved the final manuscript.

\section{Ethics approval}

All experimental procedures were approved by the Animal Experiment Committee of Nanjing Agricultural University, in accordance with the Regulations for the Administration of Affairs Concerning Experimental Animals (The State Science and Technology Commission of China, 1988). All the experimental protocols were performed in accordance with the approved guidelines and regulations.

Competing interests

The authors declare that they have no competing interests. 


\section{Publisher's Note}

Springer Nature remains neutral with regard to jurisdictional claims in published maps and institutional affiliations.

Received: 13 February 2018 Accepted: 10 May 2018

Published online: 23 May 2018

\section{References}

1. Plaizier JC, Krause DO, Gozho GN, McBride BW. Subacute ruminal acidosis in dairy cows: the physiological causes, incidence and consequences. Vet J. 2008;176(1):21-31.

2. Dong HB, Wang SQ, Jia $Y Y, N i$ YD, Zhang $Y S$, Zhuang S, Shen XZ, Zhao RQ. Long-term effects of subacute ruminal acidosis (SARA) on milk quality and hepatic gene expression in lactating goats fed a high-concentrate diet. PLoS One. 2013:8(12):e82850.

3. Li S, Khafipour E, Krause DO, Kroeker A, Rodriguez-Lecompte JC, Gozho GN, Plaizier JC. Effects of subacute ruminal acidosis challenges on fermentation and endotoxins in the rumen and hindgut of dairy cows. J Dairy Sci. 2012:95(1):294-303.

4. Chang GJ, Zhang K, XU TL, Jin D, Seyfert HM, Shen XZ, Zhuang S. Feeding a high-grain diet reduces the percentage of LPS clearance and enhances immune gene expression in goat liver. BMC Vet Res. 2015;11:11.

5. Koers WC, Britton R, Klopfenstein TJ, Woods WR. Ruminal histamine, lactate and animal performance. J Anim Sci. 1976;43(3):684-91.

6. Wagner W, Ichikawa A, Tanaka S, Panula P, Fogel WA. Mouse mammary epithelial histamine system. J Physiol Pharmacol. 2003:54(2):211-23.

7. Aschenbach JR, Gabel G. Effect and absorption of histamine in sheep rumen: significance of acidotic epithelial damage. J Anim Sci. 2000;78(2):464-70.

8. Gupta GC, Rajora VS, Pachauri SP. Histamine concentration in milk and blood during mastitis in buffaloes. Indian Vet Med J. 1999;23(1):65-6.

9. Endo Y. Simultaneous induction of histidine and ornithine decarboxylases and changes in their product amines following the injection of Escherichia coli lipopolysaccharide into mice. Biochem Pharmacol. 1982;31(8):1643-7.

10. Akdis CA, Blaser K. Histamine in the immune regulation of allergic inflammation. J Allergy Clin Immunol. 2003;112(1):15-22.

11. Aoki Y, Qiu DM, Zhao GH, Kao PN. Leukotriene B-4 mediates histamine induction of NF-kappa B and IL-8 in human bronchial epithelial cells. Am J Physiol-Lung Cell Mol Physiol. 1998;274(6):L1030-9.

12. Hill SJ, Ganellin CR, Timmerman H, Schwartz JC, Shankley NP, Young JM, Schunack W, Levi R, Haas HL. International union of pharmacology .13. Classification of histamine receptors. Pharmacol Rev. 1997:49(3):253-78.

13. Buckland KF, Williams TJ, Conroy DM. Histamine induces cytoskeletal changes in human eosinophils via the $\mathrm{H}-4$ receptor. Br J Pharmacol. 2003;140(6):1117-27.

14. DelValle J, Gantz I. Novel insights into histamine $\mathrm{H}-2$ receptor biology. Am J Physiol-Gastroint Liver Physiol. 1997;273(5):G987-96.

15. Lim HD, van Rijn RM, Ling P, Bakker RA, Thurmond RL, Leurs R. Evaluation of histamine $\mathrm{H}-1-, \mathrm{H}-2-$, and $\mathrm{H}-3$-receptor ligands at the human histamine $\mathrm{H}-4$ receptor: identification of 4-methylhistamine as the first potent and selective H-4 receptor agonist. J Pharmacol Experimental Ther. 2005;314(3):1310-21.

16. Zhu Y, Michalovich D, Wu HL, Tan KB, Dytko GM, Mannan IJ, Boyce R, Alston J, Tierney LA, Li XT, et al. Cloning, expression, and pharmacological characterization of a novel human histamine receptor. Mol Pharmacol. 2001;59(3):434-41.

17. Coge F, Guenin SP, Rique H, Boutin JA, Galizzi JP. Structure and expression of the human histamine H-4-receptor gene. Biochem Biophys Res Commun. 2001;284(2):301-9.

18. Groenen MAM, Vanderpoel JJ. REGULATION OF EXPRESSION OF MILK PROTEIN GENES - A REVIEW. Livest Prod Sci. 1994;38(2):61-78.

19. Wheeler $\Pi$, Broadhurst MK, Sadowski HB, Farr VC, Prosser CG. Stat5 phosphorylation status and DNA-binding activity in the bovine and murine mammary glands. Mol Cell Endocrin. 2001;176(1-2):39-48.

20. Zhang K, Chang GJ, Xu TL, Xu L, Guo JF, Jin D, Shen XZ. Lipopolysaccharide derived from the digestive tract activates inflammatory gene expression and inhibits casein synthesis in the mammary glands of lactating dairy cows. Oncotarget. 2016;7(9):9652-65.

21. Calsamiglia S, Cardozo PW, Ferret A, Bach A. Changes in rumen microbial fermentation are due to a combined effect of type of diet and $\mathrm{pH}$. J Anim Sci. 2008:86(3):702-11.

22. Gozho GN, Plaizier JC, Krause DO, Kennedy AD, Wittenberg KM. Subacute ruminal acidosis induces ruminal lipopolysaccharide endotoxin release and triggers an inflammatory response. J Dairy Sci. 2005;88(4):1399-403.
23. Silberberg M, Chaucheyras-Durand F, Commun L, Mialon MM, Monteils V, Mosoni P, Morgavi DP, Martin C. Repeated acidosis challenges and live yeast supplementation shape rumen microbiota and fermentations and modulate inflammatory status in sheep. Animal. 2013;7(12):1910-20.

24. Hua CF, Tian J, Tian P, Cong RH, Luo YW, Geng YL, Tao SY, Ni YD, Zhao RQ. Feeding a high concentration diet induces unhealthy alterations in the composition and metabolism of ruminal microbiota and host response in a goat model. Front Microbiol. 2017:8:12.

25. Vesuna F, Raman V. Histamine - a potential therapeutic agent for breast cancer treatment? Cancer Biol Ther. 2006;5(11):1472-3.

26. Mitchell S, Vargas J, Hoffmann A. Signaling via the NF-KB system. Wires Syst Biol Med. 2016;8(3):227-41

27. Bonizzi G, Karin M. The two NF-kappa B activation pathways and their role in innate and adaptive immunity. Trends Immunol. 2004;25(6):280-8.

28. Mohapatra DK, Reddy DS, Janaki Ramaiah M, Ghosh S, Pothula V, Lunavath S, Thomas S, Pushpa Valli SNCVL, Bhadra MP, Yadav JS. Rugulactone derivatives act as inhibitors of NF-KB activation and modulates the transcription of NF-kB dependent genes in MDA-MB-231cells. Bioorg Med Chem Lett. 2014;24(5):1389-96.

29. Kawai T, Akira S. Signaling to NF-kappa B by toll-like receptors. Trends Mol Med. 2007;13(11):460-9.

30. Akdis M, Verhagen J, Taylor A, Karamloo F, Karagiannidis C, Crameri R, Thunberg S, Deniz G, Valenta R, Fiebig H, et al. Immune responses in healthy and allergic individuals are characterized by a fine balance between allergenspecific T regulatory 1 and Thelper 2 cells. J Exp Med. 2004;199(11):1567-75.

31. Kobayashi T, Inoue I, Jenkins NA, Gilbert DJ, Copeland NG, Watanabe T. Cloning, RNA expression and chromosomal location of a mouse histamine H2 receptor gene. Genomics. 1996;37(3):390-4.

32. Muller UR, Jutel M, Reimers A, Zumkehr J, Huber C, Kriegel C, Steiner U, Haeberli G, Akdis M, Helbling A, et al. Clinical and immunologic effects of $\mathrm{H} 1$ antihistamine preventive medication during honeybee venom immunotherapy. J Allergy Clin Immun. 2008;122(5):1001-7.

33. Teuscher C, Poynter ME, Offner H, Zamora A, Watanabe T, Fillmore PD, Zachary JF, Blankenhorn EP. Attenuation of Th1 effector cell responses and susceptibility to experimental allergic encephalomyelitis in histamine $\mathrm{H}-2$ receptor knockout mice is due to dysregulation of cytokine production by antigen-presenting cells. Am J Pathol. 2004;164(3):883-92.

34. Varga C, Horvath K, Berko A, Thurmond RL, Dunford PJ, Whittle BJR. Inhibitory effects of histamine $\mathrm{H}-4$ receptor antagonists on experimental colitis in the rat. Eur J Pharmacol. 2005;522(1-3):130-8.

35. Gutzmer R, Diestel C, Mommert S, Kother B, Stark H, Wittmann M, Werfel T. Histamine $\mathrm{H} 4$ receptor stimulation suppresses IL-12p70 production and mediates chemotaxis in human monocyte-derived dendritic cells. J Immunol. 2005;174(9):5224-32.

36. de Esch IJP, Thurmond RL, Jongejan A, Leurs R. The histamine $\mathrm{H}-4$ receptor as a new therapeutic target for inflammation. Trends Pharmacol Sci. 2005;26(9):462-9.

37. Daugherty BL. Histamine $\mathrm{H}-4$ antagonism: a therapy for chronic allergy? Brit J Pharmacol. 2004:142(1):5-7.

38. Ferstl R, Akdis CA, O'Mahony L. Histamine regulation of innate and adaptive immunity. Front Biosci. 2012;17:40-53.

39. Liu CL, Wilson SJ, Kuei C, Lovenberg TW. Comparison of human, mouse, rat, and Guinea pig histamine $\mathrm{H}-4$ receptors reveals substantial pharmacological species variation. J Pharmacol Exp Ther. 2001;299(1):121-30.

40. Fruman DA, Meyers RE, Cantley LC. Phosphoinositide kinases. Annu Rev Biochem. 1998;67:481-507.

41. Sarbassov DD, Guertin DA, Ali SM, Sabatini DM. Phosphorylation and regulation of Akt/PKB by the rictor-mTOR complex. Science. 2005;307(5712):1098-101.

42. Menon S, Dibble CC, Talbott G, Hoxhaj G, Valvezan AJ, Takahashi H, Cantley LC, Manning BD. Spatial control of the TSC complex integrates insulin and nutrient regulation of $\mathrm{mTORC} 1$ at the lysosome. Cell. 2014;156(4):771-85.

43. Inoki K, Li Y, Xu T, Guan KL. Rheb GTPase is a direct target of TSC2 GAP activity and regulates mTOR signaling. Genes Dev. 2003;17(15):1829-34.

44. Jeong YJ, Cho HJ, Magae J, Lee IK, Park KG, Chang YC. Ascofuranone suppresses EGF-induced HIF-1 alpha protein synthesis by inhibition of the Akt/mTOR/p70S6K pathway in MDA-MB-231 breast cancer cells. Toxicol Appl Pharm. 2013;273(3):542-50. 